\title{
Combined Pulmonary Fibrosis and Emphysema Syndrome Complicated by Lung Cancer
}

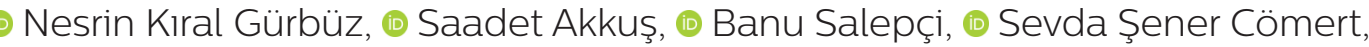 \\ (1) Elif Torun Parmaksız, (1) Coşkun Doğan
}
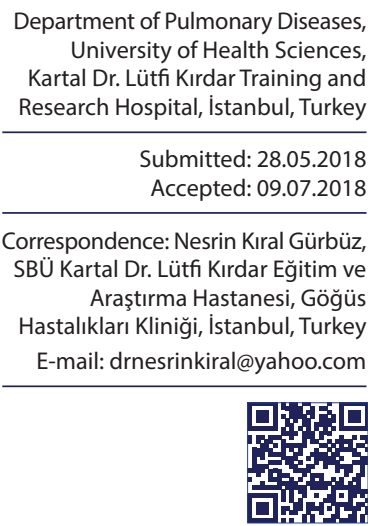

Keywords: Emphysema; lung cancer; pulmonary fibrosis; prognosis.

\begin{abstract}
Combined pulmonary fibrosis and emphysema syndrome (CPFE) is a rare disease characterized by emphysema in the upper lobes of the lung and fibrosis in the lower lobes. CPFE is an important risk factor for lung cancer (LC). Although CPFE might increase the risk of LC, the prevalence of CPFE in patients with LC and the incidence of $L C$ in patients with CPFE are unknown. LC in patients with CPFE (LC-CPFE) is associated with poor survival outcomes. The aim of this study was to present a case with CPFE to draw attention to the possibility that it may be accompanied by LC.
\end{abstract}

\section{INTRODUCTION}

Combined pulmonary fibrosis and emphysema syndrome (CPFE) is a rare disease characterized by emphysema in the upper lobes of the lung and fibrosis in the lower lobes. Characteristic features of these cases are a reduction in preserved lung volume and a decrease in diffusion capacity for carbon monoxide (DLCO) in smokers, advanced age, and male gender. ${ }^{[1-3]}$ Since these patients have a different clinical course and mortality rate from patients with only emphysema or fibrosis, establishment of the diagnosis is important. This syndrome is often complicated by pulmonary hypertension, acute lung injury, and lung cancer (LC). ${ }^{[2]}$

Since most patients with CPFE are smokers, CPFE is an important risk factor for LC. ${ }^{[4]}$ Although CPFE may increase the risk of LC, the prevalence of CPFE in patients with $L C$ and the incidence of $L C$ in patients with CPFE are unknown. ${ }^{[5]}$ This case is presented to draw attention to a potential association between CPFE and LC.

\section{CASE REPORT}

A $6 \mathrm{I}$-year-old male patient with a history of a 65 packyears of cigarette smoking applied to policlinic with lower respiratory tract symptoms and received treatment for a lung abscess. He was then referred to our hospital since there is no radiological regression (Fig. I).

The computed tomography (CT) of thorax revealed a $60 \times 51 \mathrm{~mm}$ mass lesion demonstrating cavitation, paraaortic and paratracheal lymphadenopathies and bullous changes in the upper lobes, emphysema, fibrosis in the lower lobes, and a honeycomb appearance in the left lower lobe of the lung (Figs. 2, 3). Pulmonary parenchymal findings on a thorax $\mathrm{CT}$ were evaluated as consistent with CPFE. 
The mass in the left lower lobe of the lung was also thought to be consistent with malignancy. The patient underwent pulmonary function tests (PFT) and the following values were obtained: forced vital capacity (FVC): 3.39 (79\%), forced expiratory volume in one second $\left(\mathrm{FEV}_{1}\right): 2.58$

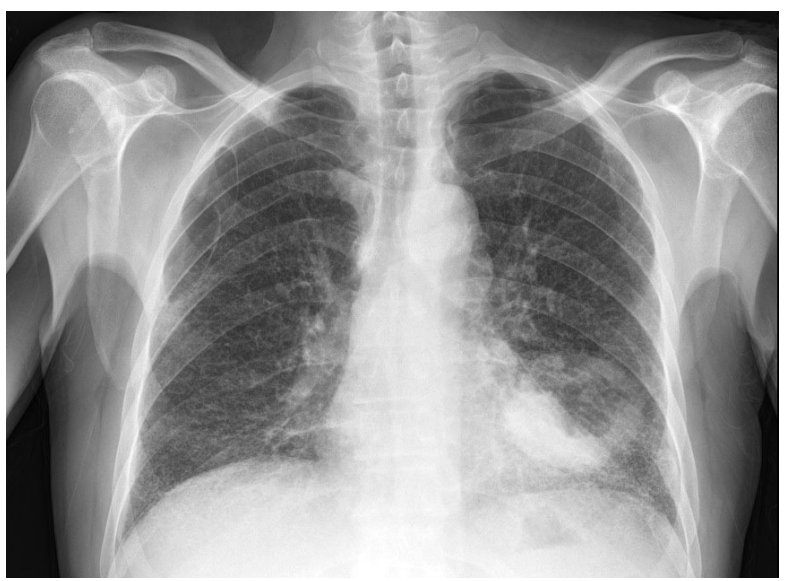

Figure 1. Posteroanterior chest X-ray: A thick-walled cavitary mass lesion in the lower zone of the left lung and a bilateral reticular pattern in lower zones.

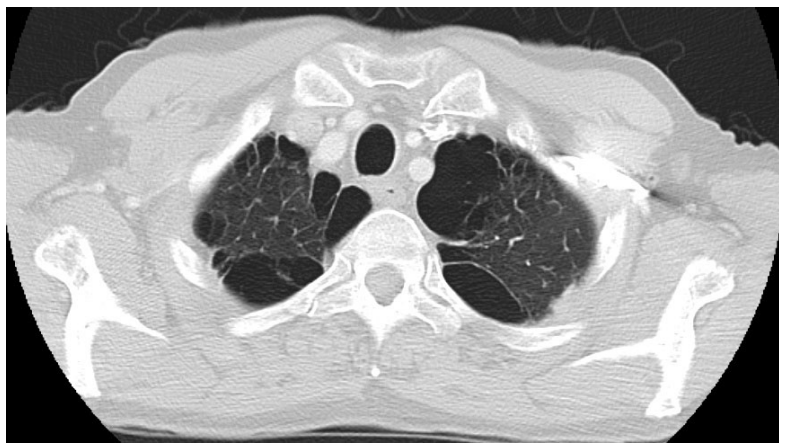

Figure 2. Thoracic computed tomography: Bullous changes and emphysematous appearance in the bilateral upper lobes.

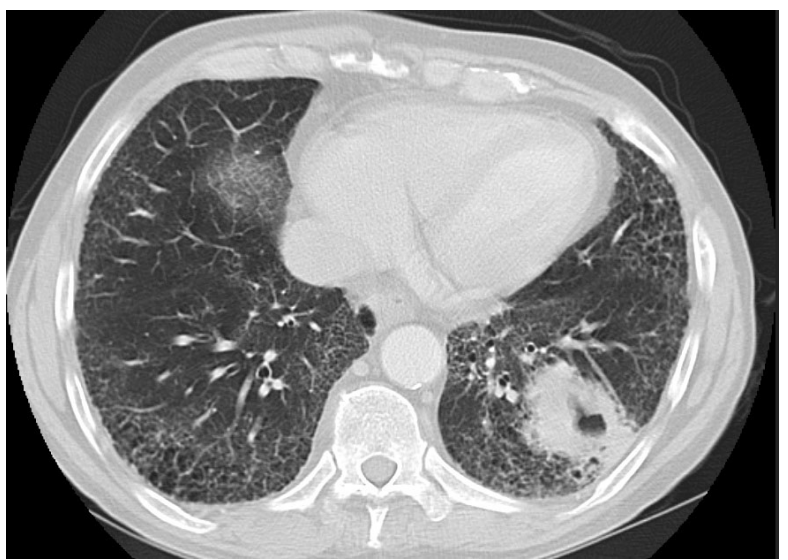

Figure 3. Thoracic computed tomography: Marked fibrosis in the bilateral lower lobes and honeycomb appearance. A thickwalled cavitary mass lesion in the posterior part of the left lung lower lobe is visible.
(77\%), FEV,/FVC: 76, DLCO: 46\%, DLCO/alveolar volume (VA): $60 \%$. A transthoracic fine needle aspiration biopsy was performed on the mass lesion in the left lower lobe of the lung after consulting with an interventional radiologist.

The pathology report indicated squamous cell carcinoma. A positron emission tomography $\mathrm{CT}$ revealed a hypermetabolic mass on the left lower lobe of the left lung, hypermetabolic mass formation consistent with primary lung malignancy, hypermetabolic lymph nodes consistent with metastasis in multiple mediastinal and abdominal lymphatics, hypermetabolic lesions consistent with metastasis in the liver, both kidneys, and the L3 vertebra. The disease was evaluated as stage 4 lung cancer and the patient was directed to the medical oncology department for treatment. It was learned that the patient died 2 months later.

\section{DISCUSSION}

Idiopathic pulmonary fibrosis (IPF) and emphysema are distinct diseases with different radiological, pathological, functional, and prognostic features. However, a new entity was first described by Cottin in 2005 as coexisting with emphysema and pulmonary fibrosis with characteristic features and defined as CPFE. Recently, cases of CPFE have been published in the literature. ${ }^{[6,7]}$

CPFE is a newly identified syndrome characterized by specific clinical findings and radiological identification with upper lobe emphysema and lower lobe fibrosis. Since the disease is not well known, diagnosis remains inadequate. Although there is not yet a consensus definition, the characteristic clinical features are used as a guide in diagnosis of this disease: male gender, heavy smoking, partial preservation observed in a PFT, marked reduction in DLCO, presence of severe symptoms, pulmonary hypertension, and a high incidence of LC. ${ }^{[8]}$

Smoking is considered to be the most important risk factor in the etiology of CPFE. ${ }^{[1,2,9]}$ A history of smoking was found in $98 \%$ of 607 patients in a meta-analysis. ${ }^{[2]}$ In the same study, it was observed that $90 \%$ of the patients were male. Emphysema has been reported to be more common in male smokers than in female smokers. ${ }^{[2]}$ Presently described is the case of a 61 -year-old male patient with a 65 pack-year smoking history.

It is thought that $35 \%$ of all idiopathic pulmonary fibrosis (IPF) patients are actually cases of CPFE, and in current studies, high rates of emphysema (8-50\%) have been reported in patients whose high-resolution computed tomography (HRCT) revealed the presence of pulmonary fibrosis $^{[2,10,1]]}$ It is important to be able to define this disease, as the clinical course of CPFE differs from that of IPF. ${ }^{[7]}$

CPFE syndrome is radiologically characterized by emphysema in the upper lobes and interstitial fibrosis in the 
lower lobes. In the upper lobes, paraseptal emphysema is more frequent, but centrilobular emphysema and bullous changes may be also seen. In the lower lobes, honeycomb cysts, an increase in reticular densities, and areas with a ground glass appearance may be encountered ${ }^{[2,6]}$ The radiological findings in this case were also characterized by bullous changes, emphysema in the upper lobes specific to CPFE, interstitial fibrosis, honeycomb cysts, and increased reticular density in the lower lobes.

PFT results for lung volume and air flow are usually normal or slightly decreased. This is due to the adverse effects of fibrosis and emphysema on respiratory functions. It is characterized by severe reduction in DLCO. The reduction in DLCO is a common finding of emphysema, fibrosis, and pulmonary vascular injury. ${ }^{[3,6,10]}$ In our patient, the FEVI was partially preserved $(77 \%)$ while the DLCO was determined to be extremely low at $46 \%$.

CPFE is often complicated by pulmonary hypertension, LC, or acute lung injury. Patients with CPFE are at increased risk for developing pulmonary hypertension, which is associated with a poor prognosis. Pulmonary hypertension is more common and more severe in patients with CPFE than in cases of chronic obstructive pulmonary disease (COPD) and IPF. Mortality is a particular concern in the presence of pulmonary hypertension. ${ }^{[7,12-14]}$

CPFE is an important risk factor for LC because most CPFE patients are smokers. ${ }^{[4]}$ Although CPFE may increase the risk of LC, the prevalence of CPFE in patients with LC and the incidence of LC in patients with CPFE are unknown. ${ }^{[5]}$ The prevalence of LC in CPFE patients has been reported to be higher $(35.8-46.8 \%){ }^{[6]}$ Kitaguchi et al. ${ }^{[6,15]}$ reported that the prevalence of LC in CPFE patients was significantly higher than that of patients with COPD $(46.8 \%$ versus $7.3 \%$ ) In a study of the HRCTs of I I 43 patients with LC, CPFE was found in $10 \mathrm{I}$ patients (8.9\%), emphysema in 404 (35.3\%), and fibrosis in 15 (1.3\%). In their large cohort study, Usui et al. found that the prevalence of CPFE in the population with LC $(8.9 \%)$ was greater than that in patients with isolated pulmonary fibrosis (1.3\%). More research is needed to explain whether CPFE is an independent risk factor for LC. ${ }^{[5]}$ In another study, patients with CPFE had a higher risk of developing LC than those with emphysema, but there was no statistically significant difference in LC risk between the CPFE and isolated IPF groups. ${ }^{[16]}$

The histological features of LC remain unclear in patients with both LC and CPFE. In a retrospective study of the data of 985 patients who underwent resection for primary LC, when compared with cases without CPFE, 72 CPFE cases with LC were found to be significantly associated with squamous cell carcinoma histology $(n=46, p<0.00 \mathrm{I})$ and a higher tumor grade $(n=44, p<0.001)$.

In the same study, it was stated that in most patients with LC and CPFE, the lesion was adjacent to the fibrotic zones $(n=59,81.9 \%)$ in the tumor periphery and that this relationship was independent of the tumor location. This study demonstrated that LC with CPFE has a different histological phenotype. It may originate from dysplastic epithelium in the fibrotic area surrounding the tumor, which is also associated with poor survival outcomes. ${ }^{[4]}$

Maeda et al. ${ }^{[17]}$ investigated the clinicopathological features of 218 patients operated on due to a diagnosis of stage I non-small cell lung cancer. The 5-year recurrence-free survival rate of CPFE patients was $36 \%$, which was significantly lower than those without CPFE (82\%; $p<0.00$ I). In multivariate analysis, the presence of CPFE was found to be one of the statistically significant independent predictors of tumor recurrence $(p=0.005)$.

CPFE syndrome generally has a poor prognosis, and a 5 -year survival rate of $35 \%$ to $80 \%$ has been reported. The average survival of patients with CPFE has ranged from 2.1 to 8.5 years in the reported studies. The main causes of death in CPFE patients are chronic respiratory failure, pulmonary hypertension, acute exacerbation, and LC. ${ }^{[6]}$ Patients with CPFE and LC have a poorer prognosis than those with emphysema or IPF alone ${ }^{[18]}$ The mean overall survival of LC patients with CPFE in one study was found to be 10.8 months, which was significantly lower than the patients with emphysema $(21.9$ months; $p<0.00 I){ }^{[5]}$

There are currently no specific effective treatments for CPFE syndrome. Smoking cessation, which is the first treatment recommended for COPD and IPF, should also be encouraged for KPFA. Quitting smoking can stop the progression of the disease. For those with other environmental exposure to what may be harmful, it is most important to avoid such exposure. To reduce acute exacerbation and infection, prolonged oxygen therapy for the illness, and vaccination against the flu and streptococcal pneumonia are recommended.

Oxygen therapy for patients with CPFE is thought to be the most appropriate treatment for hypoxemia and pulmonary hypertension. The use of inhaled bronchodilators in patients with obstruction or mixed ventilation dysfunction is sometimes a common practice. However, it is not known whether patients with CPFE benefit from bronchodilators. The efficacy of pirfenidone and nintedanib in CPFE patients is still poorly understood. More clinical trials are needed to reach a conclusion. Lung transplantation may be the only reasonable method to improve survival in patients with advanced CPFE. ${ }^{[6]}$

\section{CONCLUSION}

CPFE is a newly identified syndrome characterized by clinical features and radiologically characterized by upper lobe emphysema and lower lobe fibrosis. Since the disease is not well known, it cannot be diagnosed adequately. The 
characteristic findings of CPFE include smoking, and it is also known that CPFE is an important risk factor for LC. Further research is needed both to clarify whether CPFE is an independent risk factor for LC and also to develop new effective therapeutic strategies.

\section{Informed Consent}

Written informed consent was obtained from the patient for the publication of the case report and the accompanying images.

Peer-review

Internally peer-reviewed.

Authorship Contributions

Concept: N.K.G., S.Ş.C.; Design: N.K.G., S.Ş.C.; Data collection \&/or processing: N.K.G., S.A.; Analysis and/or interpretation: N.K.G., B.S.; Literature search: N.K.G., C.D.; Writing: N.K.G., E.T.P.; Critical review: N.K.G, S.Ş.C.

Conflict of Interest

None declared.

\section{REFERENCES}

1. Alilović M, Peroš-Golubićić T, Tekavec Trkanjec J, Hećimović A, Smojver-Ježek S. Combined pulmonary fibrosis and emphysema syndrome [Article in Croatian]. LijecVjesn 2015;137:22-6.

2. Jankowich MD, Rounds SIS. Combined pulmonary fibrosis and emphysema syndrome: a review. Chest 2012;141:222-31.

3. Özçelik N, Özsu S. A newly-defined entity: combined pulmonary fibrosis and emphysema syndrome [Article in Turkish]. Tuberk Toraks 2015;63:48-52.

4. Zhang M, Yoshizawa A, Kawakami S, Asaka S, Yamamoto H, Yasuo $\mathrm{M}$, et al. The histological characteristics and clinical outcomes of lung cancer in patients with combined pulmonary fibrosis and emphysema. Cancer Med 2016;5:2721-30.

5. Usui K, Tanai C, Tanaka Y, Noda H, Ishihara T. The prevalence of pulmonary fibrosis combined with emphysema in patients with lung cancer. Respirology 2011;16:326-31.

6. Lin H, Jiang S. Combined pulmonary fibrosis and emphy-sema (CPFE): an entity different from emphysema or pulmonary fibrosis alone. J Thoracic Dis 2015;7:767-79.

7. Duman D, Günen H. A New Definition: Combined Pulmonary Fibrosis and Emphysema Syndrome [Article n Turkish]. Respir Case Rep 2017;6:110-3.

8. Ba Aqeel SH, Biswas A, Sriram PS. The worst of both worlds-combined pulmonary fibrosis and emphysema syndrome. Ann Transl Med 2016;4:196

9. Ye Q, Huang K, Ding Y, Lou B, Hou Z, Dai H, et al. Cigarette smoking contributes to idiopathic pulmonary fibrosis associated with emphysema. Chin Med J (Engl) 2014;127:469-74.

10. Ayten Ö, Okutan O. Kombine pulmoner fibrozis ve amfizem sendromu. KOAH Bülteni 2014;2:8-11.

11. Ryerson CJ, Hartman T, Elicker BM, Ley B, Lee JS, Abbritti M, et al. Clinical features and outcomes in combined pulmonary fibrosis and emphysema in idiopathic pulmonary fibrosis. Chest 2013;144:23440.

12. Wand O, Kramer MR. The Syndrome Of Combined Pulmonary Fibrosis And Emphysema - CPFE [Article in Hebrew]. Harefuah 2018;157:28-33.

13. Papaioannou AI, Kostikas K, Manali ED, Papadaki G, Roussou A, Kolilekas L, et al. Combined pulmonary fibrosis and emphysema: The many aspects of a cohabitation contract. Respir Med 2016;117:1426.

14. Cottin V, Le Pavec J, Prévot G, Mal H, Humbert M, Simonneau G, et al; GERM"O"P. Pulmonary hypertension in patients with combined pulmonary fibrosis and emphysema syndrome. Eur Respir J 2010;35:105-11.

15. Kitaguchi Y, Fujimoto K, Hanaoka M, Kawakami S, Honda T, Kubo $\mathrm{K}$. Clinical characteristics of combined pulmonary fibrosis and emphysema. Respirology 2010;15:265-71.

16. Kwak N, Park CM, Lee J, Park YS, Lee SM, Yim JJ, et al. Lung cancer risk among patients with combined pulmonary fibrosis and emphysema. Respir Med 2014;108:524-30.

17. Maeda R, Funasaki A, Motono N, Sekimura A, Usuda K, Uramoto $\mathrm{H}$. Combined pulmonary fibrosis and emphysema predicts recurrence following surgery in patients with stage I non-small cell lung cancer. Med Oncol 2018;35:31.

18. Inomata M, Ikushima S, Awano N, Kondoh K, Satake K, Masuo M, et al. An autopsy study of combined pulmonary fibrosis and emphysema: correlations among clinical, radiological, and pathological features. BMC Pulm Med 2014;14:104.

\section{Akciğer Kanseri ile Komplike Olan Kombine Pulmoner Fibrozis ve Amfizem Sendromu}

Kombine pulmoner fibrozis ve amfizem sendromu (KPFA) akciğerin üst loblarında amfizem ve alt loblarında fibrozis ile karakterize nadir görülen bir hastalıktır. KPFA, akciğer kanseri için önemli bir risk faktörüdür. KPFA, akciğer kanseri riskini artırabilmesine rağmen, akciğer kanserli hastalarda KPFA prevalansı ve KPFA'lı hastalarda akciğer kanseri insidansı bilinmemektedir. KPFA'lı hastalarda akciğer kanserinin daha kötü prognoza sahip olduğu belirtilmektedir. Biz, KPFA'ya akciğer kanserinin eşlik edebileceğine dikkat çekmek için olgumuzu sunmayı amaçladık.

Anahtar Sözcükler: Akciğer kanseri; amfizem; prognoz; pulmoner fibrozis. 